Article

\title{
Fabrication of a Silicon Nanowire Solar Cell on a Silicon-on-Insulator Substrate
}

\author{
Shinya Kato ${ }^{1, * \mathbb{D}}$, Yasuyoshi Kurokawa ${ }^{2} \mathbb{D}$, Kazuhiro Gotoh ${ }^{2}$ and Tetsuo Soga 1 \\ 1 Department of Electrical and Mechanical Engineering, Nagoya Institute of technology, Showa-ku, \\ Nagoya-shi, Aichi 466-8555, Japan; soga@nitech.ac.jp \\ 2 Graduate School of Engineering, Nagoya University, Furo-cho, Chikusa-ku 464-8603, Japan; \\ kurokawa.yasuyoshi@material.nagoya-u.ac.jp (Y.K.); gotoh.kazuhiro@material.nagoya-u.ac.jp (K.G.) \\ * Correspondence: kato.shinya@nitech.ac.jp; Tel.: +81-52-735-7966
}

Received: 6 January 2019; Accepted: 20 February 2019; Published: 26 February 2019

check for updates

\begin{abstract}
This study proposes metal-assisted chemical etching (MAE) as a facile method to fabricate silicon nanowire (SiNW) array structures, with high optical confinement for thin crystalline silicon solar cells. Conventional SiNW arrays are generally fabricated on Si wafer substrates. However, tests on conventional SiNW-based solar cells cannot determine whether the photo-current is derived from SiNWs or from the Si wafer. Herein, SiNW arrays were fabricated on a silicon-on-insulator substrate with a 10- $\mu$ m-thick silicon layer for measuring the photocurrent of the SiNW only. The $9 \mu \mathrm{m}$-long p-type SiNW arrays were applied to a solar cell structure fabricated using an n-type H-doped amorphous Si layer, thereby confirming the photovoltaic effect. However, the device exhibited a conversion efficiency of $0.0017 \%$ because of a low short-circuit current $\left(J_{\text {sc }}\right)$ and a low open-circuit voltage $\left(V_{\mathrm{oc}}\right)$. The low $J_{\mathrm{sc}}$ resulted from a high series resistance and high absorption loss from the amorphous Si layer, whereas the low $V_{\text {oc }}$ resulted from the high surface recombination velocity of the SiNW array structure. Therefore, reducing the surface recombination of SiNW-based solar cells can improve their conversion efficiency.
\end{abstract}

Keywords: silicon nanowire; solar cell; metal-assisted chemical etching; optical confinement; silicon-on-insulator substrate

\section{Introduction}

Crystalline silicon (c-Si) solar cells have a high conversion efficiency and low-fabrication cost [1-4]. However, the efficiency of c-Si solar cells is limited by Auger recombination. Recently, c-Si solar cells, composed of ultra-thin films, have attracted considerable attention because such cells generate a higher open-circuit voltage $\left(V_{\text {oc }}\right)$ than cells with thicker films, thereby reducing Auger recombination and increasing the conversion efficiency [5,6]. However, ultra-thin c-Si solar cells have a low absorption coefficient and, therefore, have a low short-circuit current density $\left(J_{\mathrm{sc}}\right)$. Typically, the conversion efficiency of ultra-thin c-Si solar cells is limited by the trade-off between $V_{\mathrm{oc}}$ and $J_{\mathrm{sc}}$. Light management techniques are required to achieve a high $J_{\mathrm{sc}}[7-11]$, while maintaining a high $V_{\mathrm{oc}}$.

Silicon nanowire (SiNW) arrays have garnered considerable research interest as light-trapping structures because of their strong light-confinement effect [12-14]. Accordingly, a SiNW array structure can increase the absorption of a thin absorber layer. Several methods have been proposed for developing SiNW arrays, including laser ablation [15,16], thermal evaporation [17], chemical vapour deposition [18,19], reactive-ion etching [20,21], and metal-assisted chemical etching (MAE) [22-25]. Among these methods, MAE is widely used because it is simple and cost-effective. In the MAE process, silver (Ag) particles are used as a catalyst to develop large-area aligned SiNW arrays on Si-wafer substrates [26,27]. 
The application of nanowires to solar cells has been attempted in several device configurations and materials systems. In particular, the SiNWs demonstrate effective light-trapping performance and can be used in photonic crystals that require precise design. Kayes et al., reported numerous simulations, showing that a radial-type SiNW solar cell has potentially greater conversion efficiency than a flat solar cell with the same film thickness [28]. However, the conventional SiNW arrays are generally fabricated on Si-wafer substrates. When researchers deposited SiNWs onto the active layer of a SiNW solar cell, they failed to determine whether the photocurrent originated from the SiNWs or the Si wafer $[19,21,23]$. Therefore, the literature contains no reports of a solar cell structures fabricated only with single-crystalline SiNWs. Because a self-standing SiNW cannot be fabricated, constructing SiNW solar cells, that have been separated from Si-wafer substrates, is difficult. Thus, SiNW arrays have been used as anti-reflection coatings in c-Si solar cells. To develop SiNWs as an active layer for solar cells, new structure and new processes are required.

Herein, the SiNW solar cell structure was fabricated on a silicon-on-insulator (SOI) substrate to reduce the effect of bulk c-Si. This facile fabrication process employs electroless Ag plating in conjunction with MAE. For the remaining thin silicon layer, the SiNW length must be controlled to function as a carrier underneath. Herein, the effects of silver nitrate $\left(\mathrm{AgNO}_{3}\right)$ concentration in the solution, that were used in the electroless Ag plating process on the SiNW density and diameter, were investigated. The effects of the etching time of the MAE on the SiNW length, using standard p-type c-Si wafer substrates, were determined, and the morphology and optical properties of the resulting arrays were evaluated. After the SiNW fabrication process was optimised, a solar cell structure was fabricated by depositing an n-type H-doped amorphous $\mathrm{Si}$ (a-Si:H) layer onto a p-type SiNW array absorber layer, formed via MAE on the SOI substrate. Table 1 summarizes the SiNW characteristic and its structure in the solar cell between the reported literatures and this study. The length of the SiNW on the Si wafer in this case was $<1 \mu \mathrm{m}[29,30]$. However, when SiNW was used as the doping layer, it was $4 \mu \mathrm{m}$ long [31,32]. Herein, because a $9 \mu \mathrm{m}$-long SiNW on an SOI substrate was used in a solar cell, the SiNW is considered an active layer material.

Table 1. The silicon nanowire (SiNW) characteristic and its structure in solar cell between the reported literatures and this study.

\begin{tabular}{cccccc}
\hline Reference & Length of SiNW & Purpose & $\begin{array}{c}\text { Doping Concentration } \\
\text { of SiNW }\end{array}$ & $\begin{array}{c}\text { pn-Junction } \\
\text { Type }\end{array}$ & Substrate \\
\hline This study & $9 \mu \mathrm{m}$ & $\begin{array}{c}\text { Absorption } \\
\text { layer }\end{array}$ & $1015-1016 \mathrm{~cm}^{-3}$ & $\begin{array}{c}\text { Heterojunction } \\
\text { (SiNW/a-Si) }\end{array}$ & $\begin{array}{c}\text { SOI substrate } \\
\text { (SiNW:9 } \mu \mathrm{m} \\
\text { Si layer:1 } \mu \mathrm{m})\end{array}$ \\
\hline $\operatorname{Ref}[29,30]$ & $<1 \mu \mathrm{m}$ & Anti-reflection & $10^{15}-10^{16} \mathrm{~cm}^{-3}$ & $\begin{array}{c}\text { Heterojunction } \\
\text { (organic/SiNW) }\end{array}$ & Si wafer \\
\hline $\operatorname{Ref}[31,32]$ & $<4 \mu \mathrm{m}$ & Anti-reflection & $>10^{19} \mathrm{~cm}^{-3}$ & Homo-junction & Si wafer \\
\hline
\end{tabular}

The photovoltaic effect of the solar cell was confirmed. However, a very low efficiency of $0.0017 \%$ was obtained because of very low $J_{\mathrm{sc}}$ and $V_{\mathrm{oc}}$ values. Low $J_{\mathrm{sc}}$ was caused by the high series resistance and absorption loss from the n-type a-Si:H layer. The low $V_{\text {oc }}$ was caused by the high surface recombination velocity of the uncoated SiNW surfaces. These results demonstrate that reducing surface recombination is vital for improving the efficiency of SiNW-based solar cells.

\section{Materials and Methods}

\subsection{Fabrication of SiNW Arrays}

SiNWs, Si wafers (p-type, [100], 2-10 $\Omega \mathrm{cm}, 500 \mu \mathrm{m}$ thickness) were dipped into a HF solution for $1 \mathrm{~min}$ to remove the native oxide. To cover the surface with Ag particles via electroless silver plating [31], the $\mathrm{Si}$ wafers were immersed in a solution of $4.8 \mathrm{M} \mathrm{HF}$ and $\mathrm{AgNO}_{3}$ for $1 \mathrm{~min}$. The concentration of $\mathrm{AgNO}_{3}$ in the solution was varied as follows: $0.0025 \mathrm{M}, 0.005 \mathrm{M}, 0.01 \mathrm{M}, 0.015 \mathrm{M}$, 
and $0.02 \mathrm{M}$. To optimise the lengths of the SiNWs, the $\mathrm{Si}$ wafers were chemically etched using $4.8 \mathrm{M}$ $\mathrm{HF}$ and $0.15 \mathrm{M} \mathrm{H}_{2} \mathrm{O}_{2}$, at room temperature for an etching time of 1-60 min. The etched wafers were subsequently placed in an $\mathrm{HNO}_{3}$ solution to remove Ag particles. Finally, the oxide layer on the fabricated SiNW array was removed by immersing it in an HF solution. However, the surface pores were observed around the SiNWs. To remove the surface pores, the $\mathrm{HNO}_{3}$ treatment and $\mathrm{HF}$ treatment were conducted three times. The morphology of the prepared SiNW arrays was characterised using field-emission scanning electron microscopy (FE-SEM) (JEOL JSM-7001F). The reflectance of the SiNW on the Si wafer was measured using ultraviolet-visible-near-infrared (UV-Vis-NIR) spectrophotometry (Shimadzu Co., Ltd., SolidSpec-3700). The absorption coefficient of the n-type a-Si layer was measured via spectroscopic ellipsometry (J.A. Woolam, M-2000).

\subsection{Solar Cell Fabrication}

Fabrication procedure of the solar cell structure are in the Figure 1A,B schematises the fabricated solar cell structure. The SOI substrate included a $10 \mu \mathrm{m}$-thick c-Si layer (p-type, [100], 2-10 $\Omega \mathrm{cm}$ ) on an oxide insulator layer. The SiNW array structure was etched according to the optimised procedure to provide an array length of $9 \mu \mathrm{m}$. To create a p-n junction, a thick n-type a-Si:H layer was deposited onto the p-type SiNW array structure, using radio-frequency (RF) plasma-enhanced chemical vapour deposition. A mixture of $20 \mathrm{sccm} \mathrm{SiH} 4$ and $30 \mathrm{sccm} \mathrm{P_{3 }}$ was used as the precursor material at $300{ }^{\circ} \mathrm{C}$ for $30 \mathrm{~min}$. Subsequently, an $80 \mathrm{~nm}$-thick indium tin oxide (ITO) layer, with an area of $0.25 \mathrm{~mm}^{2}$, was deposited at the centre of the device via RF sputtering at $100{ }^{\circ} \mathrm{C}$ for $10 \mathrm{~min}$. The area outside the $0.25 \mathrm{~mm}^{2}$ ITO layer was then etched via reactive-ion etching using $\mathrm{CF}_{4}$ gas to remove the n-type a-Si:H and SiNW array structures. Finally, a grid Al electrode was evaporated onto the ITO layer surface. The solar cells were characterised by I-V measurements under air mass (AM) 1.5G simulated solar illumination at $100 \mathrm{~mW} / \mathrm{cm}^{2}$ and $25^{\circ} \mathrm{C}$ and by quantum efficiency measurements (Bunkoukeiki, CEP-25BX).

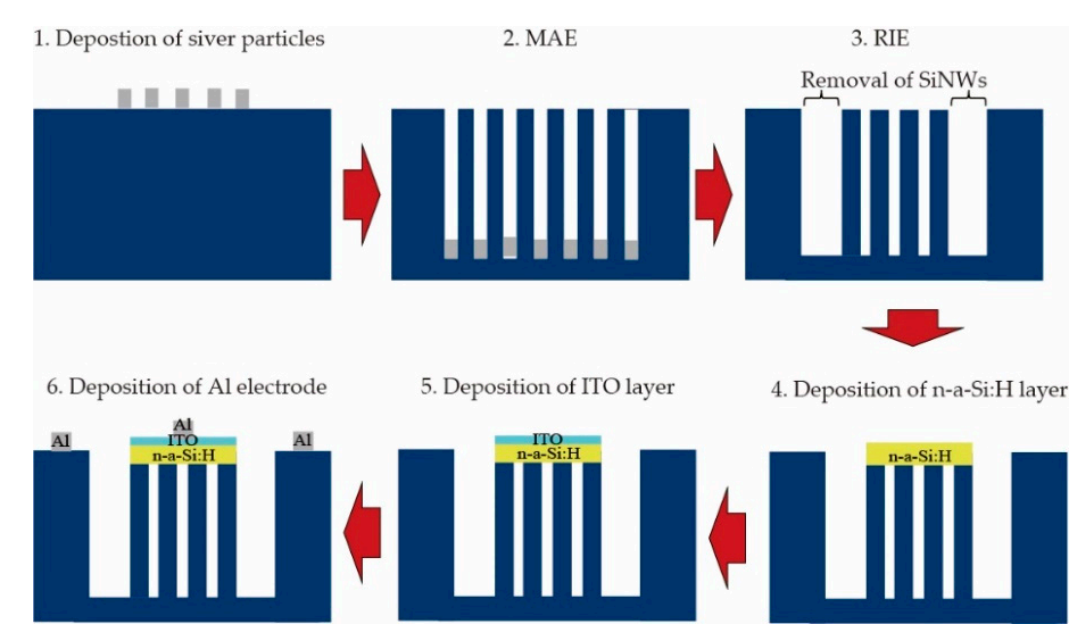

(A)

Figure 1. Cont. 


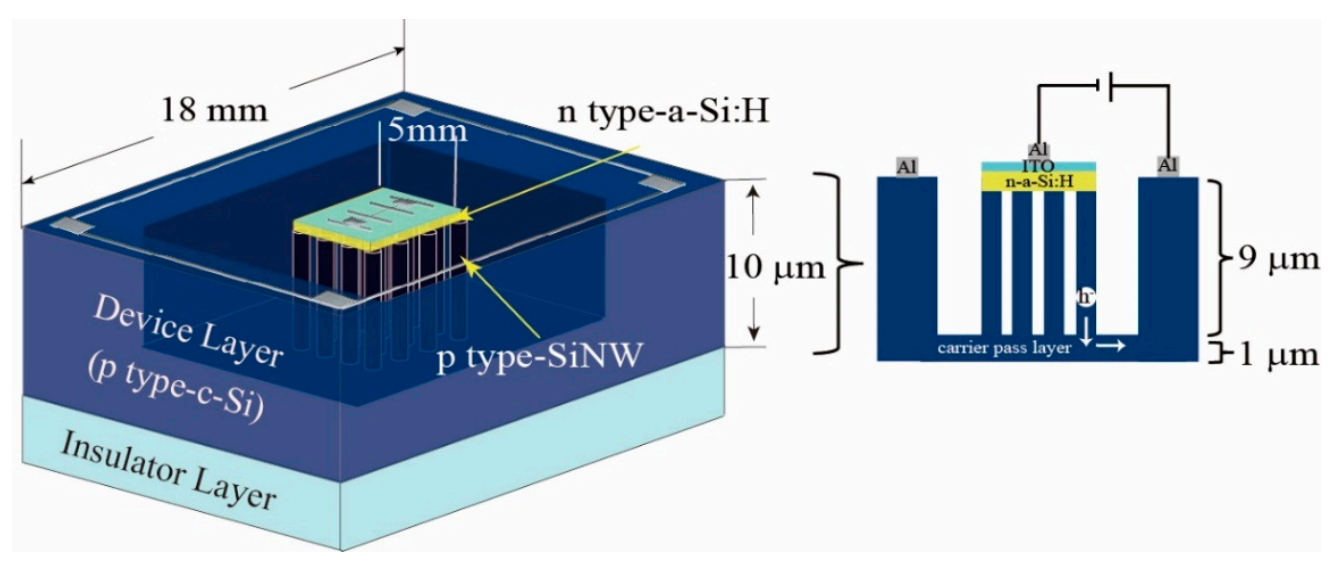

(B)

Figure 1. (A) Fabrication process for silicon nanowire (SiNW)-array-based solar cell on an silicon-on-insulator (SOI) substrate (B) Schematic of a SiNW-array-based solar cell etched on the SOI substrate.

\section{Results and Discussion}

\subsection{Evaluation of Structure and rReflectance of SiNWs on Si Wafers}

To measure the length and reflectance of the SiNWs, the SiNW arrays were fabricated on Si wafers. Figure 2 shows the SEM images of Ag particles fabricated via electroless plating from solutions with different $\mathrm{AgNO}_{3}$ concentration onto c-Si wafer substrates. When the $\mathrm{AgNO}_{3}$ concentration was $0.0025 \mathrm{M}$ (Figure 2A), the $\mathrm{Ag}$ particles were deposited onto the $\mathrm{Si}$ wafer. When the $\mathrm{AgNO}_{3}$ concentration was increased to $0.005 \mathrm{M}$ (Figure 2B), $\mathrm{Ag}$ was formed over the entire substrate, with an island structure, rather than a particle structure; large gaps were observed between the Ag islands. When $0.0025 \mathrm{M}$ and $0.005 \mathrm{M} \mathrm{AgNO}_{3}$ (Figure 2C,D) were used, Ag particles formed with non-uniform size and shape, and with large gaps among them. When $0.01 \mathrm{M} \mathrm{AgNO}_{3}$ was used (Figure 2E), $\mathrm{Ag}$ nano-particles were formed along with $\mathrm{Ag}$ islands. For $\mathrm{AgNO}_{3}$ concentrations $>0.02 \mathrm{M}$, many dendrites formed, precluding the control of the density of Ag particles, as shown in Figure 2E.

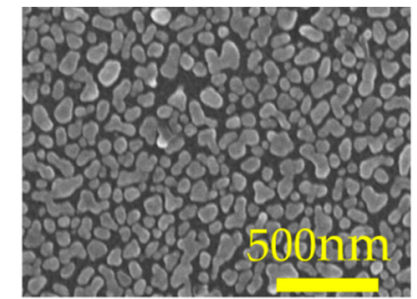

(A)

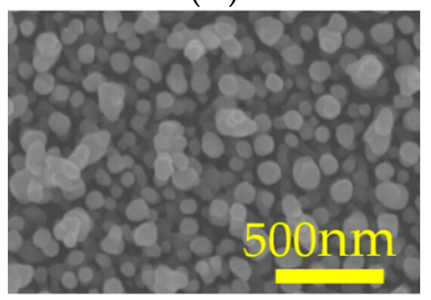

(D)

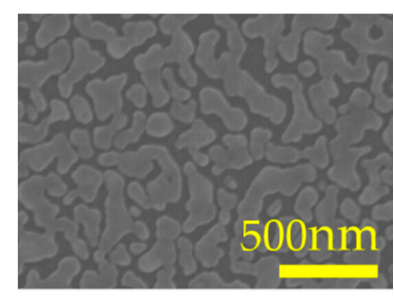

(B)

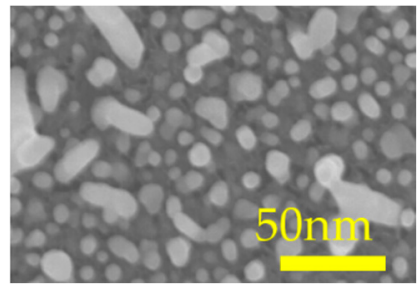

(E)

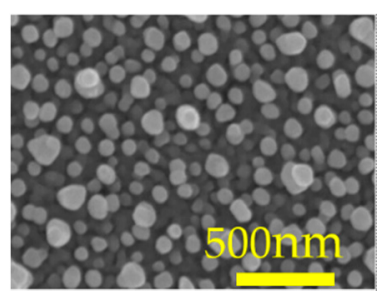

(C)

Figure 2. SEM images of Ag particles fabricated via electroless plating onto p-type c-Si wafers with $\mathrm{AgNO}_{3}$ concentrations of (A) $0.0025 \mathrm{M}$, (B) $0.005 \mathrm{M}$, (C) $0.01 \mathrm{M}$, (D) $0.015 \mathrm{M}$ and (E) $0.02 \mathrm{M}$.

Figure 3 shows the top-view SEM images of the SiNW arrays, fabricated with different $\mathrm{AgNO}_{3}$ concentrations. When $\mathrm{AgNO}_{3}$ concentrations of $0.0025 \mathrm{M}$ and $0.005 \mathrm{M}$ were used (Figure $3 \mathrm{~A}, \mathrm{~B}$ ), $\mathrm{Si}$ 
nano-walls were formed, rather than a SiNW structure. These nano-wall formations strongly resembled the gaps among the Ag particles observed in Figure 2A,B, indicating that the density of Ag particles had likely increased. Accordingly, when the $\mathrm{AgNO}_{3}$ concentration was $0.01 \mathrm{M}$, a SiNW structure emerged, and Si nano-walls were divided into several nanowires (Figure 3C).

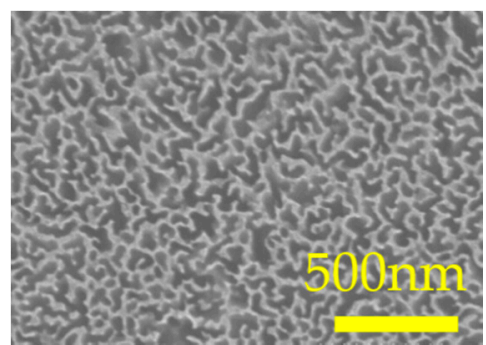

(A)

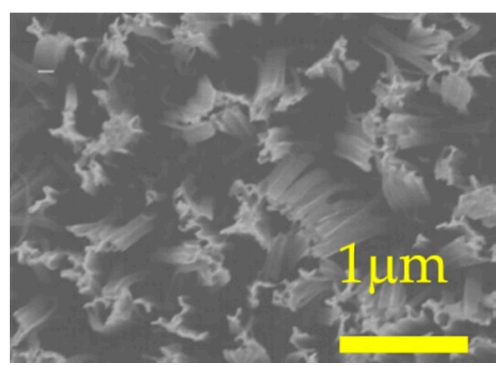

(D)

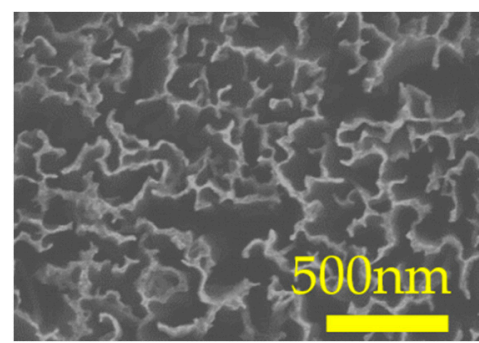

(B)

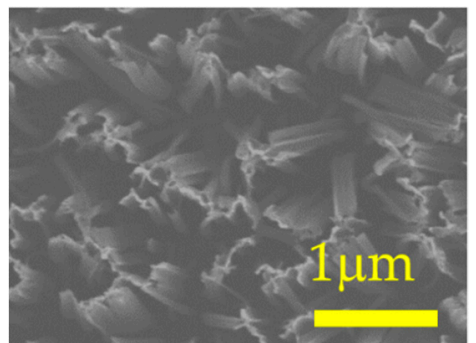

(C)

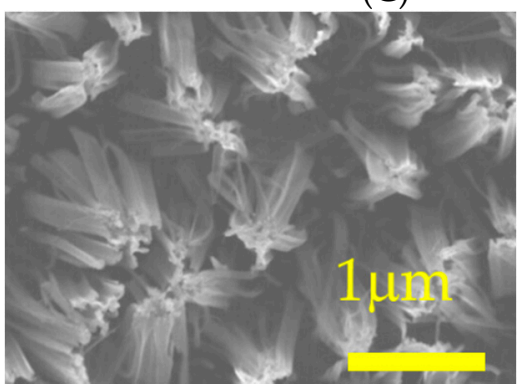

(E)

Figure 3. Top-view SEM images of etched samples fabricated using electroless plating with $\mathrm{AgNO}_{3}$ concentrations of (A) $0.0025 \mathrm{M},(\mathbf{B}) 0.005 \mathrm{M},(\mathbf{C}) 0.01 \mathrm{M}$, (D) $0.01 \mathrm{M}$, and (E) $0.02 \mathrm{M}$.

The images in Figure 3C-E indicate, that Ag particles were deposited in the gaps between the $\mathrm{Ag}$ islands, with increasing $\mathrm{AgNO}_{3}$ concentration because higher $\mathrm{AgNO}_{3}$ concentrations led to the involvement of $\mathrm{Ag}^{+}$ions in dendrite growth. Figure 4A-C shows cross-sectional SEM images of SiNW arrays formed with $\mathrm{AgNO}_{3}$ concentrations of $0.0025 \mathrm{M}, 0.005 \mathrm{M}$, and $0.01 \mathrm{M}$. These images indicate, that the SiNW arrays were fabricated vertical to the substrate, and that the concentration of $\mathrm{AgNO}_{3}$ affected only the horizontal structure of the SiNW arrays. Therefore, we selected an $\mathrm{AgNO}_{3}$ concentration of $0.01 \mathrm{M}$ to form SiNW arrays.

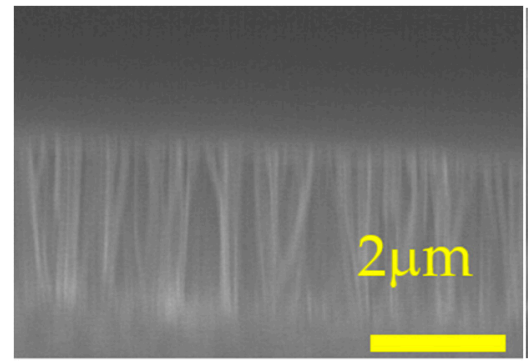

(A)

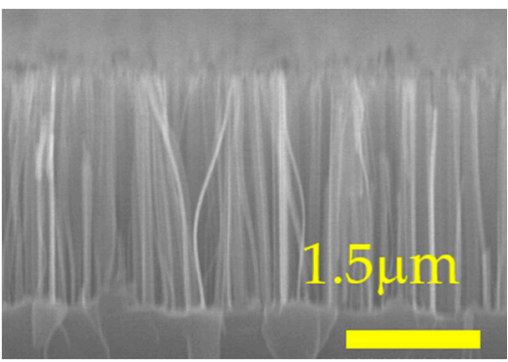

(B)

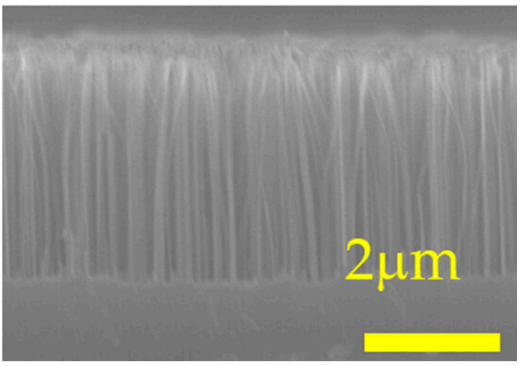

(C)

Figure 4. Cross-sectional SEM images of SiNWs fabricated via metal-assisted chemical etching with different concentrations of $\mathrm{AgNO}_{3}$ : (A) $0.01 \mathrm{M},(\mathbf{B}) 0.015 \mathrm{M}$, and (C) $0.02 \mathrm{M}$.

The SiNW array length increased with increasing etching time, and a $12 \mu \mathrm{m}$-long SiNW array was obtained after $60 \mathrm{~min}$. However, the length of the SiNW array did not linearly increase with respect 
to the etching time. The SiNW formation mechanism can be interpreted according to the following electrochemical reactions of $\mathrm{Si}$ in an $\mathrm{HF}$ and $\mathrm{H}_{2} \mathrm{O}_{2}$ solution:

$$
\begin{gathered}
4 \mathrm{Ag}^{+}+\mathrm{Si}_{6 \mathrm{~F}}^{-} \rightarrow 4 \mathrm{Ag}+\mathrm{SiF}_{6}^{2-}, \\
2 \mathrm{Ag}+\mathrm{H}_{2} \mathrm{O}_{2}+2 \mathrm{H}^{+} \rightarrow 2 \mathrm{Ag}^{+}+2 \mathrm{H}_{2} \mathrm{O} .
\end{gathered}
$$

After the consumption of $\mathrm{HF}$ and $\mathrm{H}_{2} \mathrm{O}_{2}$, new $\mathrm{HF}$ and $\mathrm{H}_{2} \mathrm{O}_{2}$ must diffuse to the bottom of the forming SiNWs. However, the length of etchant migration increases with increasing etching time because the lengths of the SiNWs increase. Hence, the SiNW length depended on the diffusion of the etching solution. Since the MAE reaction is complicated, a slight difference in wire length may occur depending on the experimental environment. These results reveal that the SiNW array length can be reasonably controlled by varying the etching time. However, to obtain a SiNW of arbitrary length, each laboratory should conduct its own preliminary experiments.

To confirm the light-confinement effect of SiNWs, the reflectance of SiNW arrays of different lengths was measured, as shown in Figure 5B. Compared with the reflectance of a bare Si wafer, the optical reflectance of all of the SiNW arrays, for wavelengths $<1000 \mathrm{~nm}$, was reduced because of a decrease in the effective refractive index of the SiNW layer and light scattering of the SiNWs. With shorter SiNWs $(0.12-7.5 \mu \mathrm{m})$, the reflectance decreased to 5-25\% compared with $35 \%$ for the bare Si wafer in the wavelength range from $600 \mathrm{~nm}$ to $1000 \mathrm{~nm}$. Additionally, when the lengths of SiNWs were less than the wavelength of light, the refractive index of the SiNW array could be considered as a middle refractive index layer between the $\mathrm{Si}$ and air. Therefore, the reflectance was reduced because the effective refractive index of the SiNW layer decreased. However, the optical reflectance from SiNWs longer than $1.4 \mu \mathrm{m}$ decreased drastically. In particular, for $7.5 \mu \mathrm{m}$-long SiNWs, the optical reflectance below $1000 \mathrm{~nm}$ decreased to less than 1\%. These results indicate that the SiNW array structures exhibit antireflection rather than light-confinement effects.

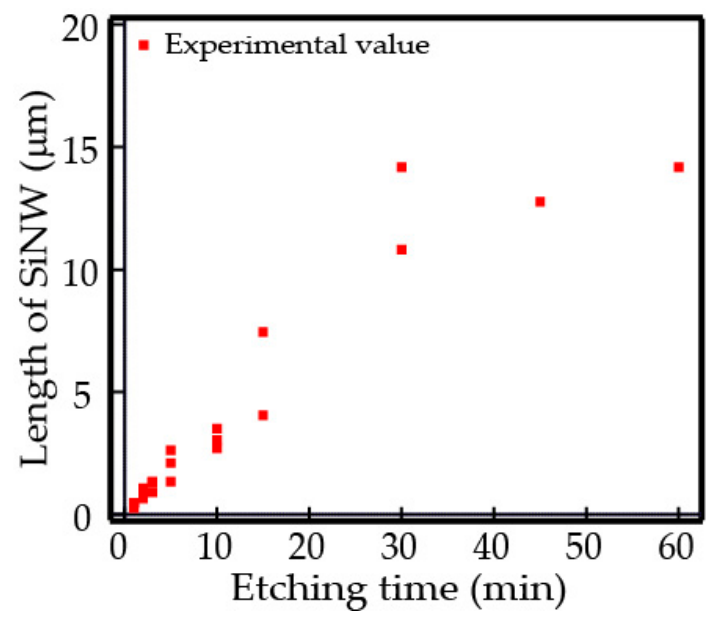

(A)

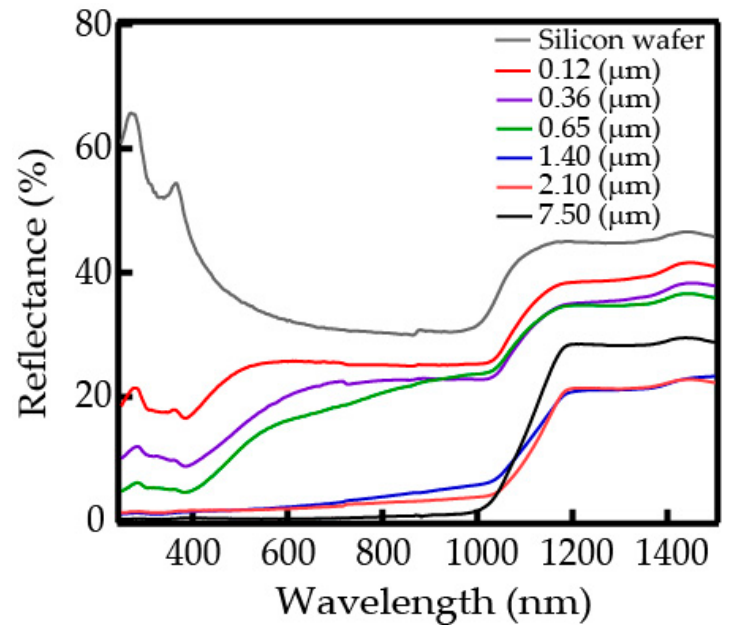

(B)

Figure 5. (A) Dependence of the SiNW array length on etching time. (B) Reflectance of the SiNW arrays with different array lengths.

\subsection{Properties of Solar Cells with the SiNW Array Structure on an SOI Substrate}

The SiNW over $7.5 \mu \mathrm{m}$ length can achieve strong light confinement. To reduce the influence of the silicon layer as much as possible, $9 \mu \mathrm{m}$-long SiNW array structure was adopted in the solar cell. Figure 6A shows the dark and illuminated I-V characteristics of the solar cell with an optimum SiNW absorber layer fabricated on an SOI substrate. A $V_{\mathrm{oc}}$ of $110 \mathrm{mV}$ was obtained, indicating that the fabricated solar cell provided a photovoltaic effect. However, the conversion efficiency of the solar cell 
was extremely low $(0.00017 \%)$. Therefore, the solar cell parameters were analysed to determine the cause of low efficiency.

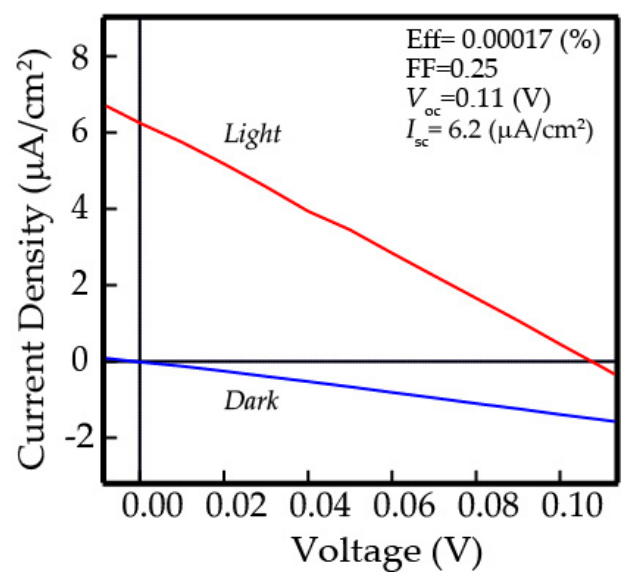

(A)

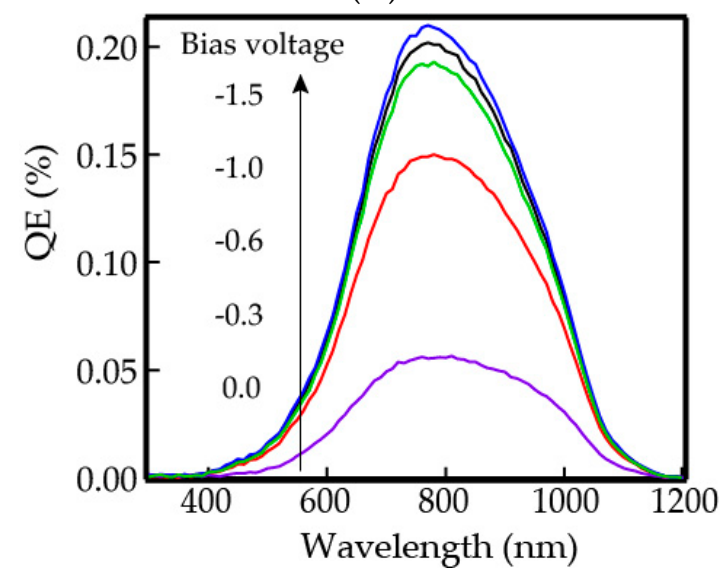

(C)

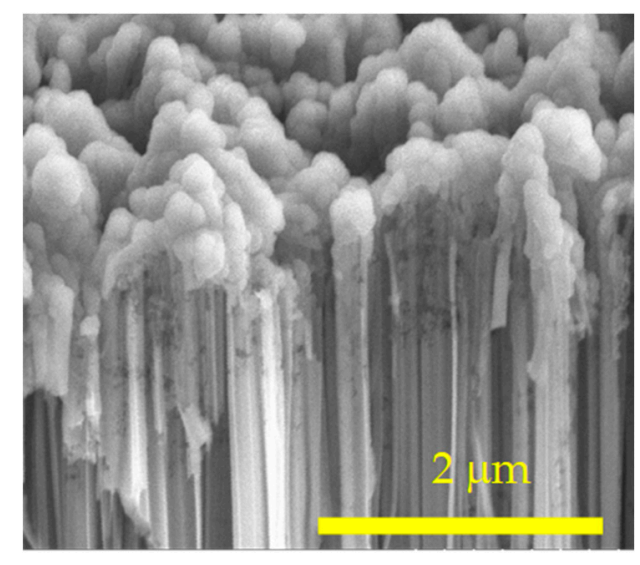

(B)

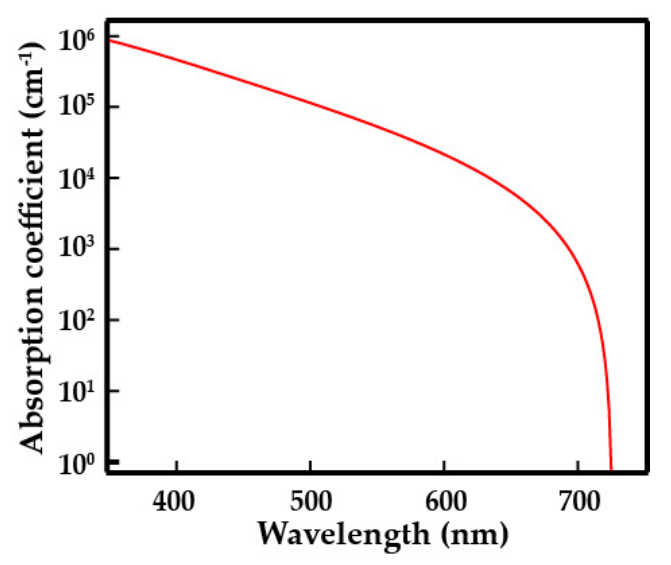

(D)

Figure 6. (A) I-V characteristics of the solar cell with an optimum SiNW absorber layer fabricated on an SOI substrate. (B) Cross-sectional SEM image of the SiNW array surface after the application of the n-type a-Si:H layer. (C) Quantum efficiency (QE) of the solar cell under a changing negative voltage from 0-1.5 V. (D) Absorption coefficient of n-type a-Si measured via spectroscopic ellipsometry.

A low $J_{\mathrm{sc}}$ of $6.2 \mu \mathrm{A} / \mathrm{cm}^{2}$ was obtained because of the high series resistance of the device layer, whose sheet resistance was $5 \mathrm{k} \Omega$ /sq. Figure $6 \mathrm{~B}$ presents a cross-sectional SEM image of the SiNW array structure after deposition of the n-type a-Si:H layer. Herein, a very thick n-type a-Si:H layer was deposited onto the SiNW array structure surface to ensure that a connection formed between each p-type SiNW and n-type layer. In a high-efficiency heterojunction Si solar cell, the thickness of a-Si is on the order of tens of nanometres. Therefore, the very thick a-Si leads to a solar cell, with high resistivity. Moreover, reaming the Si layer under the SiNW arrays contributes substantially to the high resistivity. To improve the $I_{\mathrm{sc}}$, we must consider a new structure.

Figure $6 \mathrm{C}$ shows the quantum efficiency $(\mathrm{QE})$ of the solar cell under a negative applied bias voltage with respect to the optical wavelength. The $\mathrm{QE}$ of the device is extremely low in the short-wavelength region (300-700 nm). Figure 6D shows the absorption coefficient of n-type a-Si:H. The band gap of $\mathrm{n}$-Si:H is $1.7 \mathrm{eV}$. The optical absorption coefficient of n-type a-Si is high, and the thickness of the $\mathrm{n}$-a-Si layer is approximately $300 \mathrm{~nm}$. Therefore, light with wavelengths shorter than $720 \mathrm{~nm}$ was absorbed by the n-a-Si. Because n-type a-Si has a high carrier concentration and high defect density, it did not contribute to power generation. To improve the QE in the short-wavelength 
region, the thickness of the n-a-Si:H layer should be reduced. Although p-SiNW can absorb light longer than $720 \mathrm{~nm}$, because of sheet resistance, the QE is very low in the absence of a negative bias voltage. Additionally, the $\mathrm{QE}$ at each wavelength increased with increasing negative bias voltage. The n-type a-Si:H layer was deposited only on the top of the SiNW array structure because of the high density of SiNWs (Figure 3C); this configuration strongly limited the concentrations of the n-type layer precursors at the bottom of the SiNWs. Moreover, a $467 \mathrm{~nm}$-wide depletion region, as indicated by the difference between the donor and acceptor concentrations $\left(\mathrm{Na}\right.$ (p-type SiNW) $=5 \times 10^{15} \mathrm{~cm}^{-3}$, $\mathrm{Nd}$ (n-type-a-Si) $=1 \times 10^{19} \mathrm{~cm}^{-3}$ ), formed around the surfaces of SiNWs between the n-type a-Si:H and the SiNW array structure. The negative bias enhanced the width of the depletion region and the electric fields, thereby increased the carrier collection, even though the uncoated SiNWs have a high surface recombination velocity. These results reveal that reducing the surface recombination is vital for improving the efficiency of solar cells, fabricated using SiNW array structures as the absorber layer. Our previously reported results indicated that $\mathrm{Al}_{2} \mathrm{O}_{3}$ fabricated by atomic-layer deposition is a good passivation material for a SiNW array [30]. If $\mathrm{SiNW}$ with $\mathrm{Al}_{2} \mathrm{O}_{3}$ is used in a solar cell, the $V_{\text {oc }}$ can be improved. However, the insulating $\mathrm{Al}_{2} \mathrm{O}_{3}$ film prevents the carriers from migrating to the external circuit. Thus, the inclusion of a passivation film without the SOI substrate is necessary to improve the efficiency of the device.

\section{Conclusions}

SiNW array structures were fabricated on p-type c-Si wafer substrates, using electroless Ag plating from solutions with various $\mathrm{AgNO}_{3}$ concentrations and MAE, over different etching times. With increasing $\mathrm{AgNO}_{3}$ concentration, the resulting Si nano-structures changed from the nano-walls to SiNWs, with decreasing average diameters. The length of the SiNWs depended on the diffusion of the etching solution, such that the length of the SiNWs could be reasonably controlled by adjusting the etching time. The reflectance of the SiNW array structures decreased with increasing SiNW length, indicating that the SiNW array structures with SiNW lengths $>7.5 \mu$ m exhibited an anti-reflection effect and could be expected to realise solar cells, with a high $J_{\mathrm{sc}}$, while maintaining a high $V_{\mathrm{oc}}$. Using the optimum etching process, we fabricated a solar cell, using an absorber layer composed of a SiNW array structure with a SiNW length of $9 \mu \mathrm{m}$ etched within a $10 \mu \mathrm{m}$-thick p-type c-Si layer on an insulator substrate. A hetero-junction solar cell structure was fabricated by depositing an n-type a-Si:H layer onto the SiNW array surface. The photovoltaic effect of the solar cell was confirmed. However, a low efficiency of $0.0017 \%$ was obtained because of the low $J_{\mathrm{sc}}$ and $V_{\mathrm{oc}}$ values. The low $J_{\mathrm{sc}}$ was caused by the high series resistance and by the absorption loss from the n-type a-Si:H layer. Additionally, the low $V_{\text {oc }}$ was caused by a high surface recombination velocity of the uncoated SiNW surfaces. These results demonstrate that reducing the surface recombination is vital for improving the efficiency of solar cells with SiNW array structures as the absorber. Thus, the inclusion of a passivation film, without the SOI substrate from the structure, is necessary to improve the efficiency of the device.

Author Contributions: Conceptualisation: S.K. and Y.K.; methodology: S.K.; validation S.K.; formal analysis: S.K and Y.K.; investigation: S.K.; data curation: S.K.; writing-original draft preparation: S.K.; writing-review and editing Y.K, K.G, and T.S.

Funding: This research received no external funding.

Conflicts of Interest: The authors declare no conflict of interest.

\section{References}

1. Yoshikawa, K.; Kawasaki, H.; Yoshida, W.; Irie, T.; Konishi, K.; Nakano, K.; Uto, T.; Adachi, D.; Kanmatsu, M.; Uzu, H.; et al. Silicon heterojunction solar cell with interdigitated back contacts for a photoconversion efficiency over 26\%. Nat. Energy 2017, 2, 17032. [CrossRef] 
2. Masuko, K.; Shigematsu, M.; Hashiguchi, T.; Fujishima, D.; Kai, M.; Yoshimura, N.; Yamaguchi, T.; Ichihashi, Y.; Mishrima, T.; Matsubara, N.; et al. Achievement of More Than 25\% Conversion Efficiency with Crystalline Silicon Heterojunction Solar Cell. IEEE J. Photovolt. 2014, 4, 1433-1435. [CrossRef]

3. Haase, F.; Hollemann, C.; Schafer, S.; Merkle, A.; Rienacker, M.; Krugener, J.; Brendel, R.; Peibst, R. Laser contact openings for local poly-Si-metal contacts enabling 26.1\%-efficient POLO-IBC solar cells. Sol. Energy Mater. Sol. Cells 2018, 186, 184-193. [CrossRef]

4. Benick, J.; Richter, A.; Muller, R.; Hauser, H.; Feldmann, F.; Krenckel, P.; Riepe, S.; Schindler, F.; Schubert, C.M.; Hermle, M.; et al. High-Efficiency n-Type HP mc Silicon Solar Cells. IEEE J. Photovolt. 2017, 7, 1171-1175. [CrossRef]

5. Green, M.A. Lifits on the Open-Circut Voltage and Efficiency of Silicon Solar-Cells Imposed by Intrinsic Aurge Processes. IEEE. Electron. Dev. 1984, 31, 671-678. [CrossRef]

6. Swanson, R.M. Approaching the $29 \%$ limit efficiency of silicon solar cells. In Proceedings of the Conference Record of the Thirty-First IEEE Photovoltaic Specialists Conference, Lake Buena Vista, FL, USA, 3-7 January 2005; pp. 889-894.

7. Sai, H.; Kanamori, Y.; Arafune, K.; Ohshita, Y.; Yamaguchi, M. Light trapping effect of submicron surface textures in crystalline Si solar cells. Prog. Photovolt. 2007, 15, 415-423. [CrossRef]

8. Zhao, J.H.; Wang, A.H.; Green, M.A.; Ferrazza, F. 19.8\% efficient "honeycomb" textured multicrystalline and 24.4\% monocrystalline silicon solar cells. Appl. Phys. Lett. 1998, 73, 1991-1993. [CrossRef]

9. Mavrokefalos, A.; Han, S.E.; Yerci, S.; Branham, M.S.; Chen, G. Efficient Light Trapping in Inverted Nanopyramid Thin Crystalline Silicon Membranes for Solar Cell Applications. Nano Lett. 2012, 12, 2792-2796. [CrossRef] [PubMed]

10. Green, M.A. Lambertian light trapping in textured solar cells and light-emitting diodes: Analytical solutions. Prog. Photovolt. 2002, 10, 235-241. [CrossRef]

11. Macdonald, D.H.; Cuevas, A.; Kerr, M.J.; Samundsett, C.; Ruby, D.; Winderbaum, S.; Leo, A. Texturing industrial multicrystalline silicon solar cells. Sol. Energy 2004, 76, 277-283. [CrossRef]

12. Kato, S.; Kurokawa, Y.; Watanabe, Y.; Yamada, Y.; Yamada, A.; Ohta, Y.; Niwa, Y.; Hirota, M. Optical assessment of silicon nanowire arrays fabricated by metal-assisted chemical etching. Nanoscale Res. 2013, 8. [CrossRef] [PubMed]

13. Kurokawa, Y.; Nezasa, R.; Kato, S.; Miyazaki, H.; Takahashi, I.; Usami, N. Fabrication of silicon nanowire based solar cells using $\mathrm{TiO}_{2} / \mathrm{Al}_{2} \mathrm{O}_{3}$ stack thin films. Mrs Adv. 2018, 3, 1419-1426. [CrossRef]

14. Ishikawa, R.; Kato, S.; Yamazaki, T.; Kurokawa, Y.; Miyajima, S.; Konagai, M. Solid-phase crystallization of amorphous silicon nanowire array and optical properties. Jpn. J. Appl. Phys. 2014, 53. [CrossRef]

15. Cui, Y.; Duan, X.F.; Hu, J.T.; Lieber, C.M. Doping and electrical transport in silicon nanowires. J. Phys. Chem. 2000, 104, 5213-5216. [CrossRef]

16. Zhang, Y.F.; Tang, Y.H.; Wang, N.; Yu, D.P.; Lee, C.S.; Bello, I.; Lee, S.T. Silicon nanowires prepared by laser ablation at high temperature. Appl. Phys. Lett. 1998, 72, 1835-1837. [CrossRef]

17. Pan, H.; Lim, S.; Poh, C.; Sun, H.; Wu, X.; Feng, Y.; Lin, J. Growth of Si nanowires by thermal evaporation. Nanotechnology 2005, 16, 417-421. [CrossRef]

18. Hannon, J.B.; Kodambaka, S.; Ross, F.M.; Tromp, R.M. The influence of the surface migration of gold on the growth of silicon nanowires. Nature 2006, 440, 69-71. [CrossRef] [PubMed]

19. Gunawan, O.; Guha, S. Characteristics of vapor-liquid-solid grown silicon nanowire solar cells. Sol. Energy Mater. Sol. Cells 2009, 93, 1388-1393. [CrossRef]

20. Huang, Z.P.; Fang, H.; Zhu, J. Fabrication of silicon nanowire arrays with controlled diameter, length, and density. Adv. Mater. 2007, 19, 744-748. [CrossRef]

21. Garnett, E.; Yang, P.D. Light Trapping in Silicon Nanowire Solar Cells. Nano Lett. 2010, 10, 1082-1087. [CrossRef] [PubMed]

22. Peng, K.Q.; Yan, Y.J.; Gao, S.P.; Zhu, J. Synthesis of large-area silicon nanowire arrays via self-assembling nanoelectrochemistry. Adv. Mater. 2002, 14, 1164-1167. [CrossRef]

23. Jung, J.Y.; Guo, Z.; Jee, S.W.; Um, H.D.; Park, K.T.; Lee, J.H. A strong antireflective solar cell prepared by tapering silicon nanowires. Opt. Express 2010, 18, A286-A292. [CrossRef] [PubMed]

24. Chern, W.; Hsu, K.; Chun, I.S.; de Azeredo, B.P.; Ahmed, N.; Kim, K.H. Nonlithographic Patterning and Metal-Assisted Chemical Etching for Manufacturing of Tunable Light-Emitting Silicon Nanowire Arrays. Nano Lett. 2010, 10, 1582-1588. [CrossRef] [PubMed] 
25. Peng, K.Q.; Zhang, M.L.; Lu, A.J.; Wong, N.B.; Zhang, R.Q.; Lee, S.T. Ordered silicon nanowire arrays via nanosphere lithography and metal-induced etching. App. Phys. Lett. 2007, 90. [CrossRef]

26. Kato, S.; Watanabe, Y.; Kurokawa, Y.; Yamada, A.; Ohta, Y.; Niwa, Y.; Hirota, M. Metal-Assisted Chemical Etching Using Silica Nanoparticle for the Fabrication of a Silicon Nanowire Array. Jpn. J. Appl. Phys. 2012, 51. [CrossRef]

27. Zhang, M.L.; Peng, K.Q.; Fan, X.; Jie, J.S.; Zhang, R.Q.; Lee, S.T.; Wong, N.B. Preparation of large-area uniform silicon nanowires arrays through metal-assisted chemical etching. J. Phys. Chem. C 2008, 112, 4444-4450. [CrossRef]

28. Kayes, B.M.; Atwater, H.A.; Lewis, N.S. Comparison of the device physics principles of planar and radial p-n junction nanorod solar cells. J. Appl. Phys. 2005, 97. [CrossRef]

29. Shen, X.J.; Sun, B.Q.; Liu, D.; Lee, S.T. Hybrid Heterojunction Solar Cell Based on Organic-Inorganic Silicon Nanowire Array Architecture. J. Am. Chem. Soc. 2011, 133, 19408-19415. [CrossRef] [PubMed]

30. Yu, P.C.; Tsai, C.Y.; Chang, J.K.; Lai, C.C.; Chen, P.H.; Lai, Y.C.; Tsai, P.T.; Li, M.C.; Pan, H.Z.; Huang, Y.Y.; et al. 13\% Efficiency Hybrid Organic/Silicon-Nanowire Heterojunction Solar Cell via Interface Engineering. ACS Nano 2013, 7, 10780-10787. [CrossRef] [PubMed]

31. Zeng, L.S.; Yu, X.G.; Han, Y.G.; Yang, D.R. Performance of Silicon Nanowire Solar Cells with Phosphorus-Diffused Emitters. J. Nanomater. 2012. [CrossRef]

32. Kumar, D.; Srivastava, S.K.; Singh, P.K.; Husain, M.; Kumar, V. Fabrication of silicon nanowire arrays based solar cell with improved performance. Sol. Energy Mater. Sol. Cells 2011, 95, 215-218. [CrossRef]

(C) 2019 by the authors. Licensee MDPI, Basel, Switzerland. This article is an open access article distributed under the terms and conditions of the Creative Commons Attribution (CC BY) license (http://creativecommons.org/licenses/by/4.0/). 